\title{
Intra-arterial Melphalan for Neurologic Non-Langerhans Cell Histiocytosis
}

Jasmine H. Francis, MD, Y. Pierre Gobin, MD, Ruham Alshiekh Nasany, MD, Jared Knopman, MD, Gary A. Ulaner, MD, Katherine S. Panageas, DrPH, Vaios Hatzoglou, MD, Kim Salvaggio, MSN, FNP, David H. Abramson, MD, Athos Patsalides, MD, and Eli L. Diamond, MD

Neurology ${ }^{\circledR}$ 2021;96:1091-1093. doi:10.1212/WNL.0000000000012070

Histiocytic neoplasms are rare hematologic disorders characterized by pathologic infiltration of activated histiocytes in affected tissues. The treatment of histiocytic neoplasms, including Langerhans cell histiocytosis ( $\mathrm{LCH})$ and non- $\mathrm{LCH}$, has advanced in recent years owing to targeted kinase inhibitors (BRAF and MEK) as patients with somatic mutations in the mitogen activated protein kinase (MAPK) pathway derive robust and durable responses with these therapies. ${ }^{1}$ However, there are patients with non-LCH who do not benefit from targeted therapies, particularly those with histiocytic infiltration of the nervous system, which is associated with mortality in 1 non-LCH disorder. BRAF and MEK inhibitors have limited penetration into the nervous system and worsening neurologic disease despite targeted therapy has been observed. ${ }^{2}$ These treatments can be limited or contraindicated by disease-related organ dysfunction or comorbidities. The subset of patients without MAPK alterations may not benefit from targeted therapies.

Melphalan is an alkylating agent of mustard gas derivation and small case reports/series suggest histiocytic disease is sensitive to melphalan and similar agents. ${ }^{3}$ Here we describe an innovative treatment strategy using melphalan intra-arterially delivered to neurologic foci of patients with non-LCH.

\section{Methods}

This study was Institution Review Board-approved, exempt for informed consent for retrospective research by Memorial Sloan Kettering Cancer Center. Patients gave informed consent for treatment. Three patients with neurologic or ocular sites of histiocytic disease treated with intra-arterially delivered melphalan were included. Intraarterial melphalan was delivered, as has been previously described, ${ }^{4}$ infused to one or multiple sites per treatment. The determination of target arterial vasculature and dose per infusion was a subjective process determined by anatomic site of the lesions, the hemodynamics of that site, ${ }^{5}$ and volume of tumorous disease. The total dose of melphalan was limited to $0.5 \mathrm{mg} / \mathrm{kg}$ based on prior experience with hematologic toxicity $^{4}$ (standard single agent IV dose is $1 \mathrm{mg} / \mathrm{kg}$ ). Treatment was repeated at $4-6$ week intervals, timed with recovery of blood counts. Response to treatment was evaluated by MRI, fluorodeoxyglucose (FDG) PET/CT, and functional ophthalmic assessments.

\section{Results}

The full treatment plan (dosing, vascular access, and schedule) and treatment-emergent toxicities are available from Dryad at doi.org/10.5061/dryad.m63xsj418 (tables e1 and e2). There were no procedural adverse events. Patient 1 is a 35 -year-old man with heavily pretreated Rosai-

\author{
Correspondence \\ Dr. Diamond \\ diamone1@mskcc.org
}


Dorfman disease (RDD) of the brain, ophthalmic structures including optic nerves, and no identifiable somatic mutation. His disease progressed despite systemic treatment with both chemotherapy and low-dose MEK inhibition. He received 3 infusions of intra-arterial melphalan to the vertebral and ophthalmic arteries with marked improvement in vision and radiologic lesions (figure, $A$; data available from Dryad [tables el and e2A]). Patient 2 is a 51 -year-old woman with RDD of the orbital-craniofacial structures resulting in optic neuropathy, with no somatic mutation identified, refractory to corticosteroids and radiotherapy, with retinopathy contraindicating

Figure Three Patients With Histiocytosis Treated With Intraarterial Melphalan

A

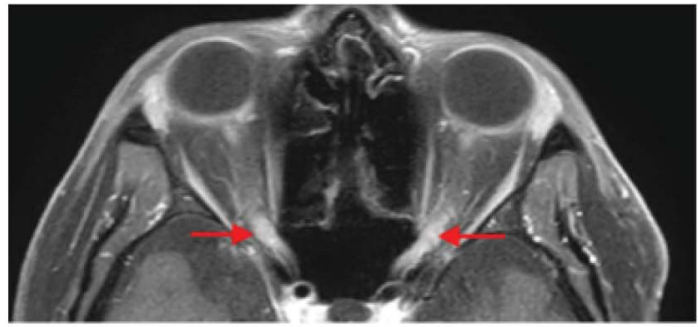

Pretreatment

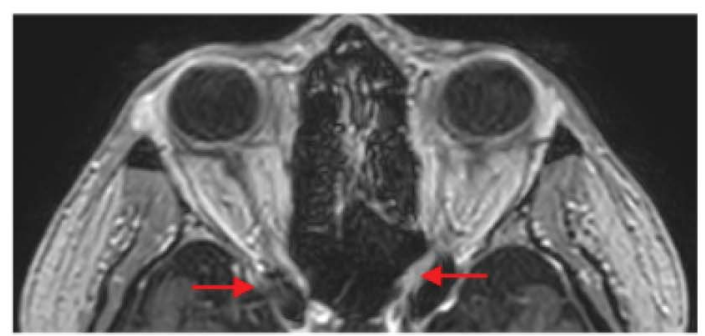

On treatment
$\mathrm{B}$

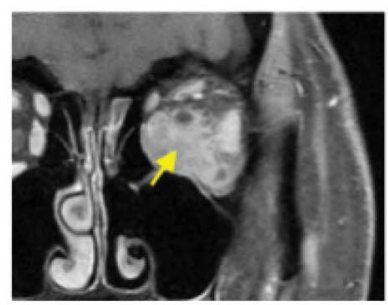

Pretreatment

C

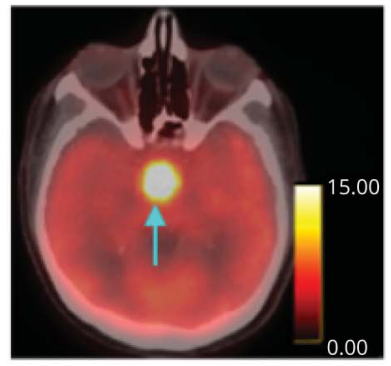

Pretreatment

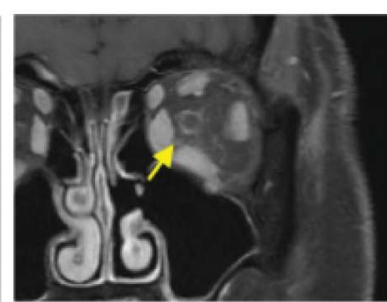

On treatment

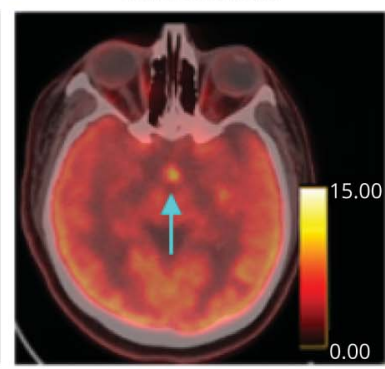

On treatment
(A) Axial postgadolinium MRI of patient 1 shows resolution of optic nerve thickening and enhancement (red arrows) after treatment with 3 intraarterial infusions. (B) Coronal postgadolinium MRI of patient 2 shows regression of left orbital tumor (yellow arrows) after treatment with 6 intraarterial infusions (C) Axial-fused PET-CT imaging of patient 3 shows resolution of hypermetabolic hypothalamic lesion (blue arrows) after treatment with 3 intraarterial infusions. empiric MEK inhibition. She received intra-arterial melphalan to several arteries over 10 infusions with regression of lesions and resolution of profound visual impairment (figure, B; data available from Dryad [tables e1 and e2B]). Patient 3 is a 41-year-old woman with isolated MAP2K1-mutated, non- $\mathrm{LCH}$ of the hypothalamus who could not access targeted therapy due to insurance denial. She received 3 infusions of intra-arterial melphalan to the basilar artery with dramatic tumoral regression (figure, C; data available from Dryad [tables e1 and e2C]).

\section{Discussion}

The premise of intra-arterial chemotherapy is to deliver a therapeutic dose to the target lesion while minimizing systemic exposure. This approach has been implemented for the treatment of primary and metastatic brain and spinal tumors using a number of agents. ${ }^{5}$ Melphalan is particularly appealing for local administration because it is rapidly eliminated and has no neurotoxicity. Melphalan is myelosuppressive in a dose-dependent manner and myelosuppression may occur following intra-arterial delivery for this patient population.

We report a novel implementation of intra-arterial chemotherapy for neurologically severe and treatment-refractory non-LCH. In our patients, this therapy was both feasible and safe, consistent with its implementation in children. Even in the era of targeted therapies for histiocytosis, this approach holds promise for mutation-negative histiocytosis or neurohistiocytosis unmanaged by targeted therapy for a variety of reasons (i.e., poor brain penetration, contraindication, or lack of access). RDD may be particularly suited for this therapy as a substantial subset of patients do not harbor MAPK pathway mutations ${ }^{6}$ and neurologic RDD is an especially morbid disease manifestation. Limitations of this treatment include restriction of this specialized technique to few centers and the fact that intra-arterial treatment is best suited for a limited number of vascular territories and therefore less practical for multifocal disease. In our patients, we observed successful intra-arterial delivery with robust clinical and radiologic response. This treatment approach would benefit from systematic evaluation of its feasibility and safety across a variety of tumor sites and arterial targets, as well as its efficacy.

\section{Acknowledgment}

The authors thank Radiology Informatics and the MSKCC Advanced Imaging Lab (SAIL) for assistance in the multimedia content of this publication; and Sue-Weil Kazzaz, Design Creative Services, Department of Marketing and Communications, Memorial Sloan Kettering Cancer Center, for her artistic work.

\section{Study Funding}

This study was supported by philanthropic funding from The Fund for Ophthalmic Knowledge (J.H.F., D.H.A.) and the Cancer Center Support Grant (P30 CA008748) (J.H.F., 
R.A.N., G.A.U., K.P., D.H.A., E.L.D.), the Frame Family Fund (E.L.D.), Joy Family West Foundation (E.L.D.), and Applebaum Foundation (E.L.D.). The sponsor or funding organization had no role in the design or conduct of this research.

\section{Disclosure}

Dr. Francis reports no disclosures. Dr. Gobin discloses stock ownership in and is chief executive officer of Serenity Medical, Inc., outside the submitted work. Drs. Nasany and Knopman report no disclosures. Dr. Ulaner is a consultant for Sanofi and reports grant support from Sanofi, Novartis, Genentech, and Puma Biotechnology. Dr. Panageas discloses stock ownership in Johnson \& Johnson, Viking Therapeutics, Catalyst, and Pfizer, outside the submitted work. Dr. Hatzoglou, K. Salvaggio, Dr. Abramson, and Dr. Patsalides report no disclosures. Dr. Diamond discloses editorial support from Pfizer Inc., outside the submitted work. Go to Neurology.org/ $\mathrm{N}$ for full disclosures.

\section{Publication History}

Received by Neurology November 12, 2020. Accepted in final form March 4, 2021.

Appendix Authors

\begin{tabular}{lll}
\hline Name & Location & Contribution \\
\hline $\begin{array}{l}\text { Jasmine H. } \\
\begin{array}{l}\text { Francis, } \\
\text { MD }\end{array}\end{array}$ & $\begin{array}{l}\text { Memorial Sloan Kettering } \\
\text { NY }\end{array}$ & $\begin{array}{l}\text { Designed and conceptualized } \\
\text { study, interpreted the data, } \\
\text { analyzed the data, drafted } \\
\text { the manuscript for } \\
\text { intellectual content }\end{array}$ \\
\hline $\begin{array}{l}\text { Y. Pierre } \\
\text { Gobin, MD }\end{array}$ & Wew York, NY & $\begin{array}{l}\text { Acquisition of data, revised } \\
\text { the manuscript for } \\
\text { intellectual content }\end{array}$ \\
\hline $\begin{array}{l}\text { Ruham } \\
\text { Alshiekh } \\
\text { Nasany, } \\
\text { MD }\end{array}$ & Memorial Sloan Kettering & $\begin{array}{l}\text { Acquisition of data, revised } \\
\text { the manuscript for } \\
\text { intellectual content }\end{array}$ \\
\hline $\begin{array}{l}\text { Jared } \\
\text { Knopman, } \\
\text { MD }\end{array}$ & Weill Cornell Medical Center, & $\begin{array}{l}\text { Acquisition of data, revised } \\
\text { the manuscript for } \\
\text { intellectual content }\end{array}$ \\
\hline
\end{tabular}

Appendix (continued)

\begin{tabular}{|c|c|c|}
\hline Name & Location & Contribution \\
\hline $\begin{array}{l}\text { Gary A. } \\
\text { Ulaner, MD }\end{array}$ & $\begin{array}{l}\text { Memorial Sloan Kettering } \\
\text { Cancer Hospital, New York, } \\
\text { NY; Molecular Imaging and } \\
\text { Therapy, Hoag Family Cancer } \\
\text { Institute, Newport Beach, CA }\end{array}$ & $\begin{array}{l}\text { Acquisition of data, revised } \\
\text { the manuscript for } \\
\text { intellectual content }\end{array}$ \\
\hline $\begin{array}{l}\text { Katherine } \\
\text { S. } \\
\text { Panageas, } \\
\text { DrPD }\end{array}$ & $\begin{array}{l}\text { Memorial Sloan Kettering } \\
\text { Cancer Hospital, New York, } \\
\text { NY }\end{array}$ & $\begin{array}{l}\text { Interpreted the data, revised } \\
\text { the manuscript for } \\
\text { intellectual content }\end{array}$ \\
\hline $\begin{array}{l}\text { Vaios } \\
\text { Hatzoglou, } \\
\text { MD }\end{array}$ & $\begin{array}{l}\text { Memorial Sloan Kettering } \\
\text { Cancer Hospital, New York, } \\
\text { NY }\end{array}$ & $\begin{array}{l}\text { Acquisition of data, revised } \\
\text { the manuscript for } \\
\text { intellectual content }\end{array}$ \\
\hline $\begin{array}{l}\text { Kim } \\
\text { Salvaggio, } \\
\text { MSN, FNP }\end{array}$ & $\begin{array}{l}\text { Weill Cornell Medical Center, } \\
\text { New York, NY }\end{array}$ & $\begin{array}{l}\text { Acquisition of data, revised } \\
\text { the manuscript for } \\
\text { intellectual content }\end{array}$ \\
\hline $\begin{array}{l}\text { David H. } \\
\text { Abramson, } \\
\text { MD }\end{array}$ & $\begin{array}{l}\text { Memorial Sloan Kettering } \\
\text { Cancer Hospital, New York, } \\
\text { NY }\end{array}$ & $\begin{array}{l}\text { Interpreted the data, revised } \\
\text { the manuscript for } \\
\text { intellectual content }\end{array}$ \\
\hline $\begin{array}{l}\text { Athos } \\
\text { Patsalides, } \\
\text { MD }\end{array}$ & $\begin{array}{l}\text { Weill Cornell Medical Center, } \\
\text { New York, NY }\end{array}$ & $\begin{array}{l}\text { acquisition of data, revised } \\
\text { the manuscript for } \\
\text { intellectual content }\end{array}$ \\
\hline $\begin{array}{l}\text { Eli L. } \\
\text { Diamond, } \\
\text { MD }\end{array}$ & $\begin{array}{l}\text { Memorial Sloan Kettering } \\
\text { Cancer Hospital, New York, } \\
\text { NY }\end{array}$ & $\begin{array}{l}\text { Designed and conceptualized } \\
\text { study, interpreted the data, } \\
\text { analyzed the data, drafted } \\
\text { the manuscript for } \\
\text { intellectual content }\end{array}$ \\
\hline
\end{tabular}

\section{References}

1. Diamond EL, Durham BH, Ulaner GA, et al. Efficacy of MEK inhibition in patients with histiocytic neoplasms. Nature 2019;567(7749):521-524.

2. Mazor RD, Weissman R, Luckman J, et al. Dual BRAF/MEK blockade restores CNS responses in BRAF-mutant Erdheim-Chester disease patients following BRAF inhibitor monotherapy. Neurooncol Adv 2020;2(1):1033.

3. Sheehan MP, Atherton DJ, Broadbent V, Pritchard J. Topical nitrogen mustard: an effective treatment for cutaneous Langerhans cell histiocytosis. J Pediatr 1991;119(2): 317-321.

4. Gobin YP. Technique of intra-arterial chemotherapy for retinoblastoma. In: Francis $\mathrm{JH}$, Abramson DH, eds. Advances in Vision Research, Volume I [online]. Springer; 2015: 27-36.

5. Gobin YP, Cloughesy TF, Chow KL, et al. Intraarterial chemotherapy for brain tumors by using a spatial dose fractionation algorithm and pulsatile delivery. Radiology 2001;218(3):724-732.

6. Durham BH, Lopez Rodrigo E, Picarsic J, et al. Activating mutations in CSF1R and additional receptor tyrosine kinases in histiocytic neoplasms. Nat Med 2019;25(12): 1839-1842.

\section{Access the 2021 Annual Meeting Anytime, Anywhere}

Access $300+$ hours of content, $140+$ programs with syllabi, $25+$ exclusive bonus presentations, and integrated CME testing-anytime and anywhere through March 31, 2022-with 2021 Annual Meeting On Demand! Visit AAN.com/AMOD to order yours today. 


\section{Neurology}

\section{Intra-arterial Melphalan for Neurologic Non-Langerhans Cell Histiocytosis}

Jasmine H. Francis, Y. Pierre Gobin, Ruham Alshiekh Nasany, et al.

Neurology 2021;96;1091-1093 Published Online before print May 12, 2021

DOI 10.1212/WNL.0000000000012070

This information is current as of May 12, 2021

\section{Updated Information \& Services}

References

Subspecialty Collections

Permissions \& Licensing

Reprints including high resolution figures, can be found at:

http://n.neurology.org/content/96/23/1091.full

This article cites 5 articles, 0 of which you can access for free at: http://n.neurology.org/content/96/23/1091.full\#ref-list-1

This article, along with others on similar topics, appears in the following collection(s):

Chemotherapy-tumor

http://n.neurology.org/cgi/collection/chemotherapytumor

Optic nerve

http://n.neurology.org/cgi/collection/optic_nerve

Orbit

http://n.neurology.org/cgi/collection/orbit

Primary brain tumor

http://n.neurology.org/cgi/collection/primary_brain_tumor

Information about reproducing this article in parts (figures,tables) or in its entirety can be found online at:

http://www.neurology.org/about/about_the_journal\#permissions

Information about ordering reprints can be found online:

http://n.neurology.org/subscribers/advertise

Neurology ${ }^{\circledR}$ is the official journal of the American Academy of Neurology. Published continuously since 1951, it is now a weekly with 48 issues per year. Copyright Copyright ( 2021 The Author(s). Published by Wolters Kluwer Health, Inc. on behalf of the American Academy of Neurology.. All rights reserved. Print ISSN: 0028-3878. Online ISSN: 1526-632X.

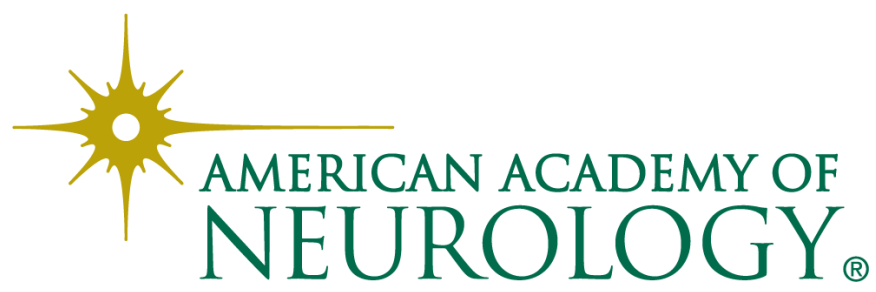

